\title{
Phytoconstituents and Nutritional Properties of the Fruits of Eleutherococcus divaricatus and Eleutherococcus sessiliflorus: A Study of Non-European Species Cultivated in Poland
}

\author{
Daniel Załuski, ${ }^{1}$ Marta Olech, ${ }^{2}$ Robert Verpoorte, ${ }^{3}$ Inamullah Khan, \\ Rafał Kuźniewski, ${ }^{1}$ and Renata Nowak ${ }^{2}$ \\ ${ }^{1}$ Department of Pharmacognosy, Ludwik Rydygier Collegium Medicum, Nicolaus Copernicus University, \\ 9 Marie Curie-Skłodowska Street, 85-094 Bydgoszcz, Poland \\ ${ }^{2}$ Chair and Department of Pharmaceutical Botany, Medical University of Lublin, 1 Chodźki Street, 20-093 Lublin, Poland \\ ${ }^{3}$ Natural Products Laboratory, Institute of Biology, Leiden University, 2300 RA Leiden, Netherlands \\ ${ }^{4}$ Department of Pharmacy, University of Peshawar, Peshawar 25120, Pakistan
}

Correspondence should be addressed to Daniel Załuski; daniel_zaluski@onet.eu

Received 23 November 2016; Revised 8 December 2016; Accepted 28 December 2016; Published 15 January 2017

Academic Editor: Elena Azzini

Copyright (C) 2017 Daniel Załuski et al. This is an open access article distributed under the Creative Commons Attribution License, which permits unrestricted use, distribution, and reproduction in any medium, provided the original work is properly cited.

\begin{abstract}
Eleutherococcus fruits have been consumed in Russia and Asia throughout the centuries. Currently, there is an increasing interest in these products by the community of Western Europe. Many people suffer from micronutrient deficiencies, known as malnutrition, which consequently influences body condition. The aim of this study was to investigate pharmaconutrition, proximate, mineral, and fatty acid composition, total phenolics content, and total flavonoids content of Eleutherococcus divaricatus and Eleutherococcus sessiliflorus fruits cultivated in Poland. Eleutherococcus divaricatus and E. sessiliflorus contain a high amount of protein and fibres (16.70\% and $12.28 \% ; 61.41 \%$ and $45.63 \%$, resp.). The fruits were generally high in $\mathrm{K}(21 \mathrm{~g} / \mathrm{kg})$ and low in sodium $(0.001 \mathrm{~g} / \mathrm{kg})$. In terms of fatty acid composition, both species had a high amount of monounsaturated fatty acids (54.84-57.95\%) and polyunsaturated fatty acids (36.22-37.0\%). Using LC-ESI-MS/MS, protocatechuic acid has been identified as the most abundant compound, ranging from 260 to $810 \mu \mathrm{g} / 100 \mathrm{~g}$ DE. Among flavonoids, hyperoside was found to be in the highest amount (120-780 $\mu \mathrm{g} / 100 \mathrm{~g}$ DE). Considering a rich chemical composition of the fruits, a better understanding of their health benefits is important in order to increase their utility and to enrich dietary sources of health promoting compounds. Because of a high amount of protein and a low calorific value, the fruits should be considered food for vegans or vegetarians.
\end{abstract}

\section{Introduction}

Species from the Eleutherococcus Maxim. genus are a valuable source of eleutherosides, phenolic acids, flavonoids, anthocyanins, triterpenoids, and biopolymers. One of the most known species of that genus is E. senticosus, which is very popular as a dietary supplement in Asia and the United States. Its products are used in the form of capsule, powder, and teabag, as health foods and drugs $[1,2]$. The main compounds, including eleutherosides, phenolic acids, and flavonoids, were characterised by HPLC, HPTLC, and LC-MS methods [3]. Apart from the aforementioned compounds, these species contain oleanolic and betulinic acids, chiisanoside, lipid acids, essential oil, and sesamin $[4,5]$.

Several reports have revealed that $E$. divaricatus and E. sessiliflorus fruits are beneficial for human health, and currently there has been a growing research interest with regard to the products of these fruits used for consumption. According to Załuski's previous studies, the fruits of species cultivated in Poland act as antioxidants, induce apoptosis in Jurkat 45 leukemic cell line, and inhibit the activity of MMP-1, MMP-2, MMP-3, and MMP-9. It is thought that chiisanoside, which was identified in the leaves, decreases the absorption of lipids. The roots and stems of E. sessiliflorus have been 
shown to have antipancreatic lipase and anti-inflammatory activities. With regard to its pharmacological aspects, E. sessiliflorus has been used in traditional medical protocols as a tonic, analgesic, antihypertensive, and antidiabetic agent. Załuski's previous studies have shown that the fruits may reduce $\mathrm{DPPH}^{*}$ radical, inhibit lipid peroxidation, and have an ion-chelating ability [6-10]. In food industry, only species native to Asia are used, while species cultivated in Europe are not yet used commercially. It is important that tested species are cultivated in other geographical zones (Poland) than native ones (Asia). The Polish climate conditions may have an influence on the chemical profile and nutritional value of fruits. They were successfully cultivated at the botanical garden in Rogów, which lies in the Central Polish Lowlands region with geographic data $51^{\circ} 49^{\prime} \mathrm{N}$ and $19^{\circ} 53^{\prime} \mathrm{E}$. The vegetative period lasts for 212 days and the average annual precipitation is $596 \mathrm{~mm}$, of which $80 \%$ occurs during the vegetative period. The average annual air temperature is $7.2^{\circ} \mathrm{C}$. The average long-term temperature is $-20.1^{\circ} \mathrm{C}$, which classified the garden to the 6bth subclimate (according to "USDA Frost Hardiness Zones") and to the second zone according to Kórnik's category. These plants are grown on the acidic, luvic, and sandy soils [11].

Phenolic compounds, known as nonnutritional ingredients in food, constitute one of the most widely occurring groups of phytochemicals with a wide range of physiological properties [12]. They are components of many fruits and vegetables, which are associated with health benefits after their consumption [13]. Clinical trials and epidemiological studies have established that dietary intake of fruits is strongly associated with a reduced risk of the civilization diseases. In the human body, they act as antiallergenic, antiatherogenic, anti-inflammatory, antimicrobial, antioxidant, and antithrombotic agents $[12,14]$.

A study of the pharmaconutrients panel of fruits can give us a better understanding of their potential beneficial effects on human health. It is a common opinion that the origin of most illnesses is due to inappropriate nutrition. Keeping in mind their long-term use by the Asians, we have decided to evaluate the quality of E. divaricatus and E. sessiliflorus cultivated in Polish climate conditions as a pharmaconutrient material and potential dietary and/or pharmaceutical product. Because those species are cultivated in another geographical zone than a native one, it is necessary to study the composition of the raw material, to ensure product quality. No comprehensive data have been reported on the proximate, mineral, fatty acids, phenolics, and flavonoids composition and caloric value of the fruits. Apart from the raw extracts, we investigated also the infusions, as very popular homemade beverages, in many cases containing different fruits.

\section{Experimental}

2.1. Plant Material. The fruits of E. divaricatus (Siebold et Zucc.) S. Y. Hu and E. sessiliflorus (Rupr. \& Maxim.) S. Y. Hu were collected at the arboretum in Rogów (Poland) in October 2016. All plant samples were deposited at the Department of Pharmacognosy, Collegium Medicum, Bydgoszcz, Poland (Cat. number ED 01-2016; ES 02-2016).
2.2. Chemicals. Folin-Ciocalteau reagent, DMSO, gallic acid, quercetin, and hesperetin were purchased from ChromaDex. Standards of gallic, protocatechuic, gentisic, 4-OH-benzoic, vanillic, caffeic, syringic, p-coumaric, ferulic, salicylic, veratric, sinapic, 3-OH-cinnamic, and rosmarinic acid, luteolin 7-glucoside, luteolin 3,7-diglucoside, rutin, hyperoside, isoquercetin, naringin, naringenin 7-glucoside, quercitrin, apigenin 7-glucoside, and LC grade acetonitrile were purchased from Sigma-Aldrich Fine Chemicals (St. Louis, MO, USA). Kaempferol 3-rutinoside and astragalin were from Carl Roth (Karlsruhe, Germany). Luteolin $4^{\prime}$-O-glucoside was obtained from LGC Standards (Dziekanów Leśny, Poland). 2,4-DNPH, ethanol, $\mathrm{FeCl}_{3}$, and $\mathrm{HNO}_{3}$ were obtained from $\mathrm{POCH}$ (Lublin, Poland). LC grade methanol $(\mathrm{MeOH})$ was purchased from J. T. Baker (Phillipsburg, USA). LC grade water was prepared using a Millipore Direct-Q3 purification system (Bedford, MA, USA). All others reagents were of analytical grade.

2.3. Accelerated Solvent Extraction (ASE). The air-dried and powdered fruits ( $5 \mathrm{~g}$ each) were placed in an extraction cell with $30 \mathrm{~g}$ of neutral silica gel. The ASE cell was placed into ASE for the extraction process (Dionex system). During the extraction process, $75 \%$ ethanol was delivered into the extraction cell. Pressure (1000 psi) was applied to maintain the solvent in its liquid state. The extraction process was repeated three times using $10 \mathrm{~mL}$ ethanol. The extraction temperature was $40^{\circ} \mathrm{C}$, and the extraction time was $15 \mathrm{~min}$. Following extraction, the extract containing the target analytes was purged from the cell using nitrogen into a collection vial for analysis. After the three extraction cycles, $30 \mathrm{~mL}$ of extracts was obtained. The solvents were dried with an evaporator under vacuum conditions at $45^{\circ} \mathrm{C}$ and subjected to lyophilisation.

2.4. Infusion Preparation. The infusion was prepared by adding $50 \mathrm{~mL}$ of distilled water $\left(95^{\circ} \mathrm{C}\right)$ to $5 \mathrm{~g}$ of fruits. The infusions were brewed for 15 minutes and were then filtered over Whatman No. 1 paper. The aqueous extracts were frozen and lyophilised.

2.5. Proximate Composition. The fruits were analysed for proximate composition: moisture by air drying at $105^{\circ} \mathrm{C}$ for $2 \mathrm{~h}$, total fat by extraction with hexane in Soxhlet's apparatus, protein by Kjeldahl's method, and ash by direct analysis at $550^{\circ} \mathrm{C}$ for $6 \mathrm{~h}$. Total carbohydrates were calculated by difference. Values represent averages of triplicate determinations performed for all analyses.

2.6. AAS of Minerals. $0.5 \mathrm{~g}$ of the dried and ground fruits was put into a burning cup, and $2 \mathrm{~mL}$ of pure $\mathrm{HNO}_{3}$ was added. The samples were incinerated in a MARS 5 microwave oven (Manufactured by CEM Corporation, USA) at a temperature of $90^{\circ} \mathrm{C}$ for $15 \mathrm{~min}$ and next at $120^{\circ} \mathrm{C}$ for $10 \mathrm{~min}$ and $210^{\circ} \mathrm{C}$ for $30 \mathrm{~min}$, and the solution was diluted to $100 \mathrm{~mL}$ with water. Minerals content was determined with a Varian SpektrAA 280FS + Autosampler SPS 3 spectrometer. Minerals and trace elements were determined using the instrumental conditions recommended for each mineral and were calculated based on the respective standard curve. 
2.7. GC-FID Fatty Acid Analysis. Fatty acids were extracted with hexane in Soxhlet's apparatus. A highly sensitive and accurate multiplex gas chromatography-linear ion trap technique was used to identify components of lipid fraction. GC/MS/MS was performed using Varian 4000 GC/MS/MS chromatograph. The GC conditions were as follows: VF$5 \mathrm{~ms}$ fused silica capillary column $(30 \times 0.32 \mathrm{~mm}$, film thickness: $0.25 \mu \mathrm{m}$ ), with the oven temperature programmed at a rate of $3^{\circ} \mathrm{C}$ from 200 (held for $10 \mathrm{~min}$ ) to $240^{\circ} \mathrm{C}$ (held for $4.67 \mathrm{~min}$ ) and injector kept at $250^{\circ} \mathrm{C}$ and detector at $300^{\circ} \mathrm{C}$, with split ratio $1: 50$. Helium was used as the carrier gas with a constant flow rate of $2.5 \mathrm{~mL} / \mathrm{min}$. The sample size was $1 \mu \mathrm{L}$ in hexane. Compounds were identified using Galaxie $^{\mathrm{TM}}$ Chromatography Data System. The following acids were analysed: C6:0 caproic; C8:0 caprylic; $\mathrm{C10:0}$ capric; C11:0 undecanoic; C12:0 lauric; C13:0 tridecanoic; C14:0 myristic; C14:1 myristoleic; C15:0 pentadecanoic; C15:1 cis10-pentadecenoic; C16:0 palmitic; C16:1 palmitoleic; C17:0 heptadecanoic; C17:1 cis-10-heptadecenoic; C18:0 stearic; cisC18:1n-9 oleic; trans-C18:1n-9 elaidic; cis-C18:2n-6 linoleic; trans-C18:2n-6 linolelaidic; C18:3n-6 $\gamma$-linolenic; C18:3n-3 $\alpha$-linolenic; C20:0 arachidic; C20:1 cis-5-eicosenoic; C20:2 cis-11,14-eicosadienoic; C20:3n-6 cis-8,11,14-eicosatrienoic; C20:4n-6 arachidonic; C20:5n-3 eicosapentaenoic; C21:0 heneicosanoic; C22:0 behenic; C22:1n-9 erucic; C22:2 cis13,16-docosadienoic; C23:0 tricosanoic; C24:0 lignoceric; C24:ln-9 nervonic. The data of total lipids were statistically analysed and expressed as mean \pm standard deviation.

2.8. Total Phenolic Content (TPC). The total phenolic content of extracts was determined using the method of Singleton and Rossi [15]. TPC was expressed as gallic acid equivalents (20$100 \mu \mathrm{g} / \mathrm{mL} ; y=0.0026 x+0.044 ; r^{2}=0.999 ; \mathrm{GAE} / \mathrm{g}$ dry extract). The experiments were done in triplicate.

2.9. Total Flavonoid Content (TFC). The TFC in investigated samples was determined using aluminium chloride and 2,4dinitrophenylhydrazine colorimetric methods [16]. TFC were expressed as means $( \pm$ SE) mg of quercetin equivalent (20$100 \mu \mathrm{g} / \mathrm{mL} ; y=0.0041 x+0.236 ; r^{2}=0.999 ;$ QEs $/ \mathrm{g}$ dry extract for $\mathrm{FeCl}_{3}$ method) and as means $( \pm \mathrm{SE}) \mathrm{mg}$ of hesperetin equivalent (HEs/g dry extract for DNPH method; 250$\left.1000 \mu \mathrm{g} / \mathrm{mL} ; y=6.374 x-0.098 ; r^{2}=0.988\right)$. The experiments were done in triplicate.

2.10. LC-ESI-MS/MS Conditions of Analysis of Phenolic Acids and Flavonoids. To evaluate phenolic acids content, the samples were analysed using a modified LC-ESI-MS/MS version of Nowacka et al. [17], with the levels of flavonoid glycosides as reported below. An Agilent 1200 Series HPLC system (Agilent Technologies, USA) equipped with a binary gradient solvent pump, a degasser, an autosampler, and column oven connected to 3200 QTRAP mass spectrometer (AB Sciex, USA) was used. Chromatographic separation was carried out at $25^{\circ} \mathrm{C}$, on an Eclipse XDB-C18 column $(4.6 \times 150 \mathrm{~mm}, 5 \mu \mathrm{m}$ particle size; Agilent Technologies, USA) with a mobile phase consisting of water containing $0.1 \% \mathrm{HCOOH}$ (solvent $\mathrm{A}$ ) and acetonitrile containing $0.1 \% \mathrm{HCOOH}$ (solvent $\mathrm{B}$ ), using $5 \mu \mathrm{L}$ injections. The flow rate was $450 \mu \mathrm{L} \mathrm{min}^{-1}$ and the gradient was as follows: $0-1 \mathrm{~min}, 18 \% \mathrm{~B} ; 1.5-5.5 \mathrm{~min}, 20 \% \mathrm{~B} ; 7-10 \mathrm{~min}$, $25 \% \mathrm{~B} ; 13-15 \mathrm{~min}, 60 \% \mathrm{~B} ; 17-21 \mathrm{~min}, 18 \%$ B. The QTRAPMS system was equipped with electrospray ionisation source (ESI) operated in the negative-ion mode. ESI worked at the following conditions: capillary temperature of $500^{\circ} \mathrm{C}$, curtain gas at $25 \mathrm{psi}$, nebulizer gas at $50 \mathrm{psi}$, and negative-ionisation mode source voltage of $-4500 \mathrm{~V}$. Nitrogen was used as curtain and collision gas. For each compound, the optimum conditions of Multiple Reaction Mode (MRM) were determined in the infusion mode. The data was acquired and processed using Analyst 1.5 software (AB Sciex, USA). Triplicate injections were made for each standard solution and sample. The analytes were identified by comparing retention time and $m / z$ values obtained by MS and $\mathrm{MS}^{2}$ with the mass spectra from corresponding standards tested under the same conditions. The calibration curves obtained in MRM mode were used for quantification of all analytes. The identified phenolic acids were quantified on the basis of their peak areas and comparison with a calibration curve obtained with the corresponding standards. Linearity ranges for calibration curves were specified. The limit of detection (LOD) and limit of quantification (LOQ) for phenolic compounds were determined at a signal-to-noise ratio of $3: 1$ and $10: 1$, respectively, by injecting a series of dilute solutions with known concentrations.

2.11. Statistical Analysis. All determination was performed in triplicate. The obtained data were subjected to statistical analysis using Statistica 7.0. (StatSoft, Cracow). The evaluations were analysed for one-factor variance analysis. Statistical differences between the treatment groups were estimated by Spearman's $(R)$ and Pearson's $(r)$ test. All statistical tests were carried out at significance level of $\alpha=0.05$.

\section{Results and Discussion}

3.1. Proximate Composition and Calorific Value. The results of proximate analysis are presented in Table 1. Eleutherococcus divaricatus contains high proportions of protein and fibres compared to E. sessiliflorus, whereas E. sessiliflorus has a higher level of carbohydrates. The carbohydrates content in E. sessiliflorus $(25.7 \%)$ is quite high when compared to $E$. divaricatus $(2.5 \%)$, which can be appropriate in formulating high carbohydrate diets. The ash content of 5.53 and $4.89 \%$ makes the fruits a good source of minerals for consumers.

Suárez-Martínez et al. reported on the content of protein in Phaseolus angularis, $P$. lunatus, $P$. vulgaris, and $P$. mungo in the range of $22.9-26.2 \%$, respectively. Overall, the content of bean proteins is said to be at the level of $20-30 \%$. In turn, soybean proteins represent about $35-40 \%$ on a dry weight basis. Despite the fact that the soybean is receiving increasing attention with respect to its health effects, it is also a wellrecognized allergenic food for sensitive people. Additionally, soybean should not be ingested in a high amount by males because soy food and soy isoflavones are associated with lower sperm concentration $[18,19]$. In this case, particular attention should be directed to the vegetarian or vegan males. Taking into account the proximate composition, it can be pointed out that the fruits of $E$. divaricatus should enrich any 
TABle 1: Proximate composition (\%) of the fruits of E. divaricatus and E. sessiliflorus*.

\begin{tabular}{lcc}
\hline Nutrient [\%] & E. divaricatus & E. sessiliflorus \\
\hline Moisture & 7.72 & 8.21 \\
Ash & 5.53 & 4.89 \\
Protein & $16.70 \pm 0.53$ & $12.28 \pm 0.39$ \\
Fat & 6.9 & 3.26 \\
Carbohydrates & 2.5 & 25.7 \\
Fibres & $61.41 \pm 20.26$ & $45.63 \pm 15.06$ \\
Calorific value & $1046 \mathrm{~kJ} / 100 \mathrm{~g}$ & $1132 \mathrm{~kJ} / 100 \mathrm{~g}$ \\
& $255 \mathrm{kcal} / 100 \mathrm{~g}$ & $273 \mathrm{kcal} / 100 \mathrm{~g}$ \\
\hline
\end{tabular}

* Results are means \pm standard deviation of triplicates.

diet where high protein and fibre content is needed. Taking into account the calorific value, the fruits may be used in slimming diet.

3.2. Mineral Content. Antioxidant activity of plants is, very often, associated with the amount of mineral constituents. Some of them ( $\mathrm{Se}, \mathrm{Zn}, \mathrm{Mn}$, and $\mathrm{Cu}$ ) are often thought to be a dietary antioxidant protecting cells from oxidative damage [20]. The concentrations of the mineral components of the fruits according to the mineralisation and identification methods are reported in Table 2 . The variation in the amount of minerals between two species has been noticed. The main elements of both species were $\mathrm{Ca}$ and $\mathrm{K}$. The fruits of $E$. divaricatus have a high level of $\mathrm{Mn}$ and $\mathrm{Zn}$ compared to E. sessiliflorus. Eleutherococcus divaricatus contains a high amount of Fe.

Other studies indicated that the E. senticosus fruits, collected in Korea, contain 465, 1433, 199, and $13 \mathrm{mg} / \mathrm{kg}$ dry weight of $\mathrm{Ca}, \mathrm{Mg}, \mathrm{Mn}$, and $\mathrm{Zn}$, respectively [21]. Compared with species cultivated in Poland, there is a difference in the level of $\mathrm{Ca}$ and $\mathrm{Mn}$. Both species contain higher level of $\mathrm{Ca}$ and lower level of Mn. A major finding is that the species native to Asia does not contain Fe, a factor that excludes these fruits as an ingredient of antianemic diet. It is worth noting that $E$. divaricatus has higher Fe content than the Rosa canina L. fruits $(27.0 \mathrm{mg} / \mathrm{kg})$, which is very popular in the diet of the Europeans. Moreover, the results obtained in the present study indicated a higher content of $\mathrm{Mn}, \mathrm{Zn}$, and $\mathrm{Cu}$ than that in the Rosa canina L. and Rosa damascena Mill. fruits [22]. It should be mentioned that E. divaricatus contains more $\mathrm{Zn}$ and $\mathrm{Mn}$ than walnut of kernels (from 17.9 to 20.6 and 17.5 to $22.2 \mathrm{mg} / \mathrm{kg}$ ). According to a WHO report, over 2000 million people in developing countries have iron deficiency anemia [23]. The global burden of disease estimates showed that, among the 26 major risk factors of the global burden of disease, iron deficiency ranks ninth overall, while zinc deficiency is eleventh [24]. In that case, the fruits, especially of E. divaricatus, should be considered a new dietary ingredient that may be included in the antianemic diet. In order to receive the best results, a combination of these fruits has to be included in the diet.

3.3. Fatty Acid Composition. A total of 36 different fatty acids were identified by GC-FID analysis. 16 different fatty acids were identified in E. sessiliflorus, and 14 were identified in E. divaricatus, contained at various concentrations in all the analysed fruits (Table 3). The fruits of E. sessiliflorus have a threefold higher amount of $\alpha$-linolenic acid (ALA) than $E$. divaricatus (2.27 and $0.79 \%$ ), the acid whose occurrence is limited. The $\alpha$-linolenic acid is recognized as a promising therapeutic agent for numerous health disorders acting as the preventive and neuroprotective constituent of the human diet. The predominant unsaturated fatty acids obtained were oleic acid and elaidic acid up to 57\%. Overall, in the present study, a majority of the fatty acids were monounsaturated (57.95\% and 54,84\% in E. divaricatus and E. sessiliflorus, resp.). The MUFA content was higher than that of walnut, which is an important ingredient of the European diet. Another popular product is virgin coconut oil, which is suggested as a functional food with a high amount of MUFA and PUFA. However, this oil contains a lower amount of C18:1 (6.5\%) than the analysed samples. It has been established that MUFA has a beneficial effect on health by raising highdensity lipoprotein cholesterol (HDLC) [25]. Apart from MUFA, the high content of PUFA and omega- 6 has also been assayed.

3.4. TPC and TFC in the Fruits. As it was shown in Table 4, all ethanol extracts contain a higher amount of TPC than the infusions (45.3 and $52.3 \mathrm{mg} / \mathrm{g}$ DE for E. divaricatus and $E$. sessiliflorus, resp.). In turn, the summed amount of flavonoids ranged from 18.4 to $23.0 \mathrm{mg} / \mathrm{g} \mathrm{DE}$ for E. divaricatus and $E$. sessiliflorus. We found that flavonoid content obtained by aluminium chloride reaction was much higher than those obtained by DNPH reaction. This can indicate that the species contain more compounds with the $\mathrm{OH}$ group which are responsible for the high antioxidant activity of the extracts.

The contents of phenolic compounds were within the range of those previously reported for the various Eleutherococcus species, cultivated in Poland. Załuski and Janeczko [26] showed that the fresh fruits of $E$. divaricatus and $E$. sessiliflorus contain 6.1 and $6.9 \mathrm{mg} / \mathrm{g}$ dry sample of polyphenols. Shohael et al. [27] studied E. sessiliflorus growing in Korea but reported a lower concentration of phenols than that now estimated. The TPC content found in the $75 \%$ ethanolic extracts from the spring leaves ranged from 20.3 to $37.2 \mathrm{mg} / \mathrm{g}$, followed by the fresh fruits $(6.1-19.7 \mathrm{mg} / \mathrm{g})$ and the roots $(6.9-$ $10.6 \mathrm{mg} / \mathrm{g})$. Jang et al. [28] revealed that the fruits of E. senticosus collected in Korea contained from 197.9 to $334.3 \mathrm{mg} /$ g of polyphenols, while the TFC ranged from 41.2 to $203.7 \mathrm{mg} /$ g.

Our findings showed that the investigated Eleutherococcus fruits contain more TPC than the blueberries fruits, which in Poland or other European countries are very widely used in food products and for medical purposes and are recognized as rich sources of polyphenols. According to Grace et al. [29], blueberries contain from 22.7 to $39.3 \mathrm{mg} / \mathrm{g}$ extract of polyphenols. According to Załuski and Janeczko [26], the content of TPC and TFC in the fruits is not changed during storage and quantified between 4.11 and $4.35 \mathrm{~g} / 100 \mathrm{~g}$ for the freshly dried fruits from E. senticosus and E. henryi. After 1year storage, the amount did not change significantly and was between 3.85 and 4.13 for E. senticosus and E. henryi. Heo 
TABLE 2: Mineral compositions of the fruits $[\mathrm{mg} / \mathrm{kg}]$.

\begin{tabular}{lccccccccc}
\hline & $\mathrm{Fe}$ & $\mathrm{Ca}$ & $\mathrm{Mg}$ & $\mathrm{K}$ & $\mathrm{Na}$ & $\mathrm{Cu}$ & $\mathrm{Zn}$ & $\mathrm{Mn}$ & $\mathrm{Se}$ \\
\hline E. divaricatus & $30 \pm 3.5$ & 3310 & 1460 & 2100 & 1 & $5.3 \pm 0.8$ & $27.5 \pm 2.8$ & 105.5 & 0.84 \\
E. sessiliflorus & $20 \pm 2.9$ & 1730 & 1240 & 2790 & 25 & $3 \pm 0.62$ & $10 \pm 1.8$ & 4 & 0.41 \\
\hline
\end{tabular}

TABLE 3: Fatty acid composition of the fruits of E. divaricatus and $E$. sessiliflorus [\%].

\begin{tabular}{lcc}
\hline Fatty acid & E. divaricatus $^{*}$ & E. sessiliflorus $^{*}$ \\
\hline C10:0 & - & 0.06 \\
C12:0 & 0.06 & 0.15 \\
C13:0 & 0.08 & - \\
C14:0 & 0.16 & 0.19 \\
C15:0 & 0.05 & 0.13 \\
C16:0 & $3.76 \pm 0.22$ & $4.96 \pm 0.29$ \\
C16:1 & - & 0.76 \\
C17:0 & 0.06 & 0.10 \\
C17:1 & - & 0.10 \\
C18:0 & $0.85 \pm 0.09$ & $1.27 \pm 0.14$ \\
C18:1n9c + C18:1n9t & $\mathbf{5 7 . 6 1} \pm 1.86$ & $\mathbf{5 3 . 7 3} \pm 1.74$ \\
C18:2n6c + C18:2n6t & $\mathbf{3 5 . 4 3} \pm 0.43$ & $\mathbf{3 4 . 7 3} \pm 0.42$ \\
C18:3n3 (alpha) & $0.79 \pm 0.06$ & $2.27 \pm 0.17$ \\
C20:0 & $0.19 \pm 0.01$ & $0.23 \pm 0.01$ \\
C20:1 & 0.34 & 0.26 \\
C22:0 & 0.35 & 0.63 \\
C24:0 & 0.23 & 0.41 \\
SFA & 5.77 & 8.11 \\
MUFA & 57.95 & 54.84 \\
PUFA & 36.22 & 37.00 \\
Omega-3 & 0.79 & 2.27 \\
Omega-6 & 35.43 & 34.73 \\
\hline Ren & &
\end{tabular}

${ }^{*}$ Results are means \pm standard deviation of triplicates.

et al. [21] reported a lower concentration of polyphenols and flavonoids in ethanol, methanol, and water extract of the $E$. senticosus fruits growing in Korea $(0.3,0.6$, and $0.6 \%$ and 0.20 , 0.23 , and $0.3 \%$, resp.) than that now estimated.

3.5. LC-ESI-MS/MS Analyses for Phenolic Acids and Flavonoids. Results of the optimization of conditions of LCESI-MS/MS analysis are given in Tables S1, S2, S3, and S4 in Supplementary Material available online at https://doi.org/ $10.1155 / 2017 / 8374295$. The concentrations of individual compounds, which were quantified by comparison of peak areas with the calibration curves obtained for the corresponding standards, are reported in Table 5. Among fourteen phenolic acids (gallic, protocatechuic, gentisic, 4-OH-benzoic, 3-OHbenzoic, vanillic, syringic, $p$-coumaric, ferulic, veratric, salicylic, 3-OH-cinnamic, sinapic, and rosmarinic), just five were qualitatively and quantitatively determined in the fruits (protocatechuic, caffeic, $p$-coumaric, ferulic, and salicylic). Protocatechuic acid occurs in the highest amount $(260-810 \mu \mathrm{g} /$ $100 \mathrm{~g} \mathrm{DE}$ ). In turn, LC-ESI-MS/MS analysis of flavonoids revealed the presence of six flavonoids, of which hyperoside was determined in the highest amount $(120-780 \mu \mathrm{g} / 100 \mathrm{~g}$ $\mathrm{DE})$. This is the first time astragalin is found in Eleutherococcus spp. Overall, smaller quantities of phenolic acids and flavonoids were present in the infusions than in the $75 \%$ ethanol extracts.

Only a few studies have focused on the assessment of phenolic acids and flavonoids present in roots, leaves, and fruits of species native to Asia and Russia. Data in the literature indicated that Kurkin et al. [30] identified free phenolic acids (syringic, $p$-coumaric, vanillic, $p$-hydroxybenzoic, caffeic, and ferulic acids) and depside (chlorogenic acid) in the roots of E. senticosus growing in Russia. Kurkin et al. [30] identified protocatechuic, chlorogenic, and caffeic acids in the roots of a Chinese sample. Bączek identified rosmarinic, chlorogenic, ferulic, and caffeic acids in the roots, fruits, and stem barks of six species [31, 32].

Protocatechuic acid has been identified in Hibiscus sabdariffa L. (2.8 and $11.9 \mathrm{mg} / \mathrm{g}$ aqueous and ethanol extracts from roselle calyx) and Euterpe oleracea Mart. $(630 \mathrm{mg} / \mathrm{L}$ of oil) $[33,34]$. In turn, the content of protocatechuic acid in Allium cepa L. was dependent on a type of raw material. The highest content was determined in a dried material $(76.3 \mu \mathrm{g} / \mathrm{g})$ contrary to a fresh material $(5.8 \mu \mathrm{g} / \mathrm{g})$ [35]. Comparing the results obtained in this work with the cited ones, it is concluded that Eleutherococcus spp. contain a higher amount of protocatechuic acid. This acid also occurs in various fruits such as berries (raspberry, blueberry, mulberry, cranberry, and gooseberry), wine, honey, and soybean. Protocatechuic acid has been found to have various activities such as antibacterial, antidiabetic, antiulcer, anti-inflammatory, and cardiac effects [36].

Data related to flavonoids in Eleutherococcus spp. are scarce and mainly relate to Załuski et al's previous studies $[9,26]$. Zhao et al. [37] reported on the presence of hyperin in the green and mature fruits of E. sessiliflorus (630.7 and $430.1 \mu \mathrm{g} / \mathrm{g}$ ). Lee at al. [38] have detected rutin, hyperin, quercetin, and kaempferol in E. divaricatus, planted in Korea. Other studies on the content of rutin, hyperin, quercetin, and kaempferol, in different species of E. divaricatus and $E$. sessiliflorus collected in South Korea, have shown the differences dependent on the plant part. The roots and stems were rich in rutin $(1.9,3.5$ and $4.2,0.8 \mathrm{mg} / \mathrm{g}$ for E. divaricatus and E. sessiliflorus) [39].

\section{Conclusions}

Our results demonstrate that the fruits of Eleutherococcus species, rich in polyphenols and nutrients, have promising potential as a new income source of agriculture and industry in natural products and foods. The fruits may become ingredients of herbal teas or natural products where a high amount of phytochemicals and nutrients is needed. 
TABLE 4: TPC and TFC in extracts from the fruits of E. divaricatus and E. sessiliflorus (mg GAE/g and QEs/g dry extract* ).

\begin{tabular}{lcccc}
\hline Species & TPC & \multicolumn{2}{c}{ Flavonoid content } & DNPH \\
\hline${ }^{\wedge}$ E. divaricatus & $52.3 \pm 0.5$ & $12.3 \pm 0.11$ & $6.0 \pm 0.04$ & $18.4 \pm 0.02$ \\
${ }^{\wedge}$ E. sessiliflorus & $45.3 \pm 0.5$ & $17.3 \pm 0.08$ & $5.7 \pm 0.01$ & $23.0 \pm 0.03$ \\
${ }^{-E}$. divaricatus & $41.1 \pm 0.5$ & $12.0 \pm 0.5$ & $6.1 \pm 0.5$ & $18.2 \pm 0.5$ \\
$\cdot$ E. sessiliflorus & $40.6 \pm 0.5$ & $10.0 \pm 0.5$ & $5.9 \pm 0.5$ & $15.0 \pm 0.5$ \\
\hline
\end{tabular}

${ }^{*}$ Results are means \pm standard deviation of triplicates.

${ }^{\wedge}$ The $75 \%$ ethanol extracts; ${ }^{\circ}$ the infusions.

TABLE 5: Phenolic acid contents expressed in $\mu \mathrm{g}$ per $100 \mathrm{~g}$ of dry weight of extracts.

\begin{tabular}{|c|c|c|c|c|}
\hline & \multicolumn{2}{|c|}{$75 \%$ ethanol } & \multicolumn{2}{|c|}{ Infusion } \\
\hline & E. divaricatus & E. sessiliflorus & E. divaricatus & E. sessiliflorus \\
\hline \multicolumn{5}{|c|}{ Phenolic acids } \\
\hline Protocatechuic acid & 693 & 818 & 270 & 267 \\
\hline Caffeic acid & 133 & 0.8 & 22.8 & 19.8 \\
\hline$p$-Coumaric acid & Trace & Trace & 5.2 & 5.3 \\
\hline Ferulic acid & 11.1 & 6.1 & 4.1 & 5.9 \\
\hline Salicylic acid & 0.15 & Trace & Trace & Trace \\
\hline \multicolumn{5}{|c|}{ Flavonoids } \\
\hline Rutin & 90 & Trace & 0.002 & Trace \\
\hline Hyperoside & 780 & 360 & 120 & 280 \\
\hline Isoquercetin & Trace & 100 & Trace & Trace \\
\hline Naringin & Trace & Trace & 0.9 & 1.0 \\
\hline Astragalin & 30.0 & 10 & - & - \\
\hline Naringenin 7-glucoside & 5.0 & 3.0 & - & 4.0 \\
\hline
\end{tabular}

-: not detected; Trace: trace amounts. Mean values of three replicate assays with standard deviation.

\section{Abbreviations}

TPC: Total phenolics content

TFC: Total flavonoids content

MUFA: Monounsaturated fatty acids

PUFA: Polyunsaturated fatty acids

DNPH: 2,4-Dinitrophenylhydrazine

$\mathrm{FeCl}_{3}$ : Aluminium chloride

GA: Gallic acid

HE: Hesperetin equivalent

QE: Quercetin equivalent

AAS: Atomic absorption spectroscopy.

\section{Competing Interests}

The authors declare no competing financial interests.

\section{Acknowledgments}

The paper was developed using the equipment purchased within the project The Equipment of Innovative Laboratories Doing Research on New Medicines Used in the Therapy of Civilization and Neoplastic Diseases within the Operational Program Development of Eastern Poland 2007-2013, Priority Axis I Modern Economy, Operations I.3 Innovation Promotion.

\section{References}

[1] J. Yang, S. Zhao, C. Yu, and C. Li, "Large-scale plantlet conversion and ex vitro transplantation efficiency of siberian ginseng by bioreactor culture," The Scientific World Journal, vol. 2013, Article ID 829067, 8 pages, 2013.

[2] M. Schmidt, M. Thomsen, O. Kelber, and K. Kraft, "Myths and facts in herbal medicines: Eleutherococcus senticosus (Siberian ginseng) and its contraindication in hypertensive patients," Botanics: Targets and Therapy, vol. 4, pp. 27-32, 2014.

[3] Ł. Cieśla, D. Załuski, H. D. Smolarz, M. Hajnos, and M. Waksmundzka-Hajnos, "HPTLC-densitometric method for determination of eleutherosides B, E, and E1 in different Eleutherococcus species," Journal of Chromatographic Science, vol. 49, no. 3, pp. 182-188, 2011.

[4] A. Panossian, G. Wikman, and H. Wagner, "Plant adaptogens III. Earlier and more recent aspects and concepts on their mode of action," Phytomedicine, vol. 6, no. 4, pp. 287-300, 1999.

[5] D. Załuski, H. Smolarz, and A. Chomicki, "TLC screening for eleutherosides $\mathrm{B}, \mathrm{E}$, and $\mathrm{E} 1$, and isofraxidin in the roots of six Eleutherococcus species cultivated in Poland," Acta Chromatographica, vol. 22, no. 4, pp. 581-589, 2010.

[6] W. Jiang, W. Li, L. Han et al., "Biologically active triterpenoid saponins from Acanthopanax senticosus," Journal of Natural Products, vol. 69, no. 11, pp. 1577-1581, 2006.

[7] S. K. Jung, T. G. Lim, J. E. Kim et al., "Inhibitory effect of ERK1/2 and AP-1 by hyperoside isolated from Acanthopanax sessiliflorus," Food Chemistry, vol. 130, no. 4, pp. 915-920, 2012. 
[8] W. J. Jun, H. S. Seong, H. Chun, E. J. Lim, K. I. Kim, and H. Y. Cho, "Determination of antioxidative potentials of Acanthopanax sessiliflorus (Rupr. \& Maxim.) Seem. in differentiated HL-60 cells," Food Chemistry, vol. 105, no. 4, pp. 1557-1563, 2007.

[9] D. Załuski, H. D. Smolarz, and U. Gawlik-Dziki, "Bioactive compounds and antioxidative, antileukemic and anti-MMPs activity of Eleutherococcus species cultivated in Poland," Natural Product Communications, vol. 7, no. 11, pp. 1483-1486, 2012.

[10] D. Załuski, M. Olech, A. Galanty et al., "Phytochemical content and pharma-nutrition study on Eleutherococcus senticosus fruits intractum," Oxidative Medicine and Cellular Longevity, vol. 2016, Article ID 9270691, 10 pages, 2016.

[11] J. Tumiłowicz and P. Banaszczak, "Trees and shrubs of Aquifoliaceae family in Rogów glinna arboreta," Rocznik Dendrologiczny, vol. 55, pp. 41-56, 2007.

[12] D. H. Watson, Performance Functional Foods, Woodhead Publishing in Food Science and Technology, Cambridge, UK, 2003.

[13] G. P. P. Lima, F. Vianello, C. R. Corrêa, R. A. S. Campos, and M. G. Borguini, "Polyphenols in fruits and vegetables and its effect on human health," Food and Nutrition Sciences, vol. 5, no. 11, pp. 1065-1082, 2014.

[14] R. H. Liu, "Health-promoting components of fruits and vegetables in the diet," Advances in Nutrition, vol. 4, no. 3, pp. 384S392S, 2013.

[15] V. L. Singleton and J. A. Rossi, "Colometry of total phenolics with phosphomolybdic-phospotungstic acid reagents," American Journal of Enology Viticulture, vol. 16, pp. 144-158, 1965.

[16] C.-C. Chang, M.-H. Yang, H.-M. Wen, and J.-C. Chern, "Estimation of total flavonoid content in propolis by two complementary colorimetric methods," Journal of Food and Drug Analysis, vol. 10, no. 3, pp. 178-182, 2002.

[17] N. Nowacka, R. Nowak, M. Drozd, M. Olech, R. Los, and A. Malm, "Analysis of phenolic constituents, antiradical and antimicrobial activity of edible mushrooms growing wild in Poland," LWT_Food Science and Technology, vol. 59, pp. 689694, 2014.

[18] S. E. Suárez-Martínez, R. A. Ferriz-Martínez, R. Campos-Vega, J. E. Elton-Puente, K. T. Carbot, and T. García-Gasca, "Bean seeds: leading nutraceutical source for human health," CyTAJournal of Food, vol. 14, no. 1, pp. 131-137, 2016.

[19] M. J. Messina, "Legumes and soybeans: overview of their nutritional profiles and health effects," American Journal of Clinical Nutrition, vol. 70, no. 3, pp. 439-450, 1999.

[20] C. Dani, L. S. Oliboni, D. Pra et al., "Mineral content is related to antioxidant and antimutagenic properties of grape juice," Genetics and molecular research : GMR, vol. 11, no. 3, pp. 31543163, 2012.

[21] S. J. Heo, H. Y. Ahn, M. J. Kang, J. H. Lee, J. Y. Cha, and Y. S. Cho, "Antioxidative activity and chemical characteristics of leaves, roots, stems and fruits extracts from Acanthopanax senticosus," Journal of Life Science, vol. 21, no. 7, pp. 1052-1059, 2011.

[22] S. Kazaz, H. Baydar, and S. Erbas, "Variations in chemical compositions of Rosa damascena Mill, and Rosa canina L. Fruits," Czech Journal of Food Sciences, vol. 27, no. 3, pp. 178-184, 2009.

[23] WHO/UNICEF/United Nations University, "Iron deficiency anaemia assessment, prevention and control: a guide for programme managers," Document WHO/NHD/01.3, World Health Organization, Geneva, Switzerland, 2001.

[24] WHO, The World Health Report 2002: Reducing Risks, Promoting Healthy Life, WHO, Geneva, Switzerland, 2002.
[25] N. Kalogeropoulos, N. K. Andrikopoulos, and M. Hassapidou, "Dietary evaluation of Mediterranean fish and molluscs panfried in virgin olive oil," Journal of the Science of Food and Agriculture, vol. 84, no. 13, pp. 1750-1758, 2004.

[26] D. Załuski and Z. Janeczko, "Variation in phytochemicals and bioactivity of the fruits of Eleutherococcusspecies cultivated in Poland," Natural Product Research, vol. 29, no. 23, pp. 2207-2211, 2015.

[27] A. M. Shohael, D. Chakrabarty, M. B. Ali et al., "Enhancement of eleutherosides production in embryogenic cultures of Eleutherococcus sessiliflorus in response to sucrose-induced osmotic stress," Process Biochemistry, vol. 41, no. 3, pp. 512-518, 2006.

[28] D. Jang, J. Lee, S. H. Eom et al., "Composition, antioxidant and antimicrobial activities of Eleutherococcus senticosus fruit extracts," Journal of Applied Pharmaceutical Science, vol. 6, no. 3, pp. 125-130, 2016.

[29] M. H. Grace, D. Esposito, K. L. Dunlap, and M. A. Lila, “Comparative analysis of phenolic content and profile, antioxidant capacity, and anti-inflammatory bioactivity in wild alaskan and commercial vaccinium berries," Journal of Agricultural and Food Chemistry, vol. 62, no. 18, pp. 4007-4017, 2014.

[30] V. A. Kurkin, G. G. Zapesochnaya, and V. V. Bandyshev, "Phenolic compounds of Eleutherococcus senticosus," Khimiya Prirodnykh Soedinenii, vol. 6, pp. 854-856, 1991.

[31] K. Bączek, "Accumulation of biologically active compounds in Eleuthero (Eleutherococcus senticosus/Rupr. et Maxim./ Maxim.) grown in Poland," Herba Polonica, vol. 55, pp. 7-13, 2009.

[32] K. Bączek, "Diversity of Eleutherococcus genus in respect of biologically active compounds accumulation," Herba Polonica, vol. 60, no. 3, 2014.

[33] C.-Y. Chao and M.-C. Yin, "Antibacterial effects of roselle calyx extracts and protocatechuic acid in ground beef and apple juice," Foodborne Pathogens and Disease, vol. 6, no. 2, pp. 201-206, 2009.

[34] L. A. Pacheco-Palencia, S. Mertens-Talcott, and S. T. Talcott, "Chemical composition, antioxidant properties, and thermal stability of a phytochemical enriched oil from Açai (Euterpe oleracea Mart.)," Journal of Agricultural and Food Chemistry, vol. 56, no. 12, pp. 4631-4636, 2008.

[35] M. Drozd, M. Thomas, and R. Nowak, "Determination of phenolic acids in raw garlic (Allium sativum L.) and onion (Allium cepa L.) bulbs," Annales Universitatis Mariae Curie-Sklodowska, Sectio DDD: Pharmacia, vol. 24, no. 1, pp. 121-127, 2011.

[36] X. Li, X. Wang, D. Chen, and S. Chen, "Antioxidant activity and mechanism of protocatechuic acid in vitro," Functional Foods in Health and Disease, vol. 7, pp. 232-244, 2011.

[37] L. Zhao, Q. An, F. Qin, and Z. Xiong, "Simultaneous determination of six constituents in the fruit of Acanthopanax sessiliflorus (Rupr. et Maxim.) Seem. by HPLC-UV,' Natural Product Research, vol. 28, no. 7, pp. 500-502, 2014.

[38] J. M. Lee, J. Lee, J. J. Lee, S. Ch. Lee, and S. Lee, "Yield analysis of flavonoids in Acanthopanax divaricatus and A. koreanum grown using different cultivation methods," Natural Product Sciences, vol. 22, no. 1, pp. 25-29, 2016.

[39] J. M. Lee, D. G. Lee, J. Kim, and S. Lee, "Content analysis of flavonoids in the stems and roots of Acanthopanax species in different countries," Asian Journal of Chemistry, vol. 26, no. 12, pp. 3511-3514, 2014. 


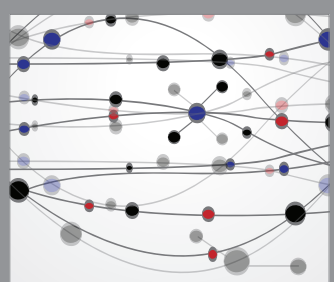

The Scientific World Journal
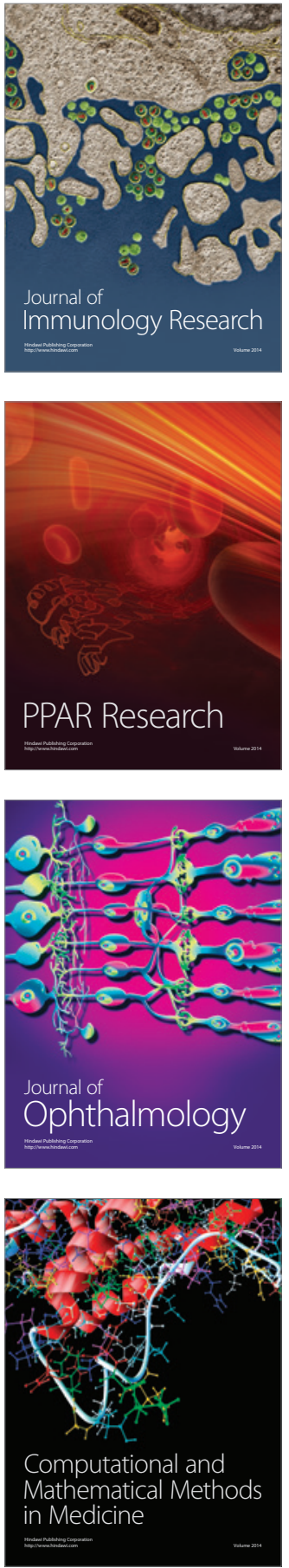

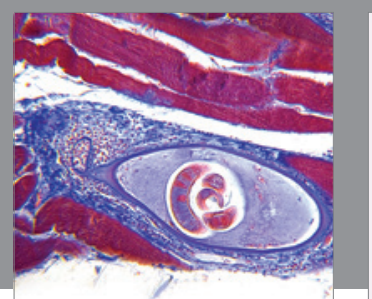

Gastroenterology Research and Practice
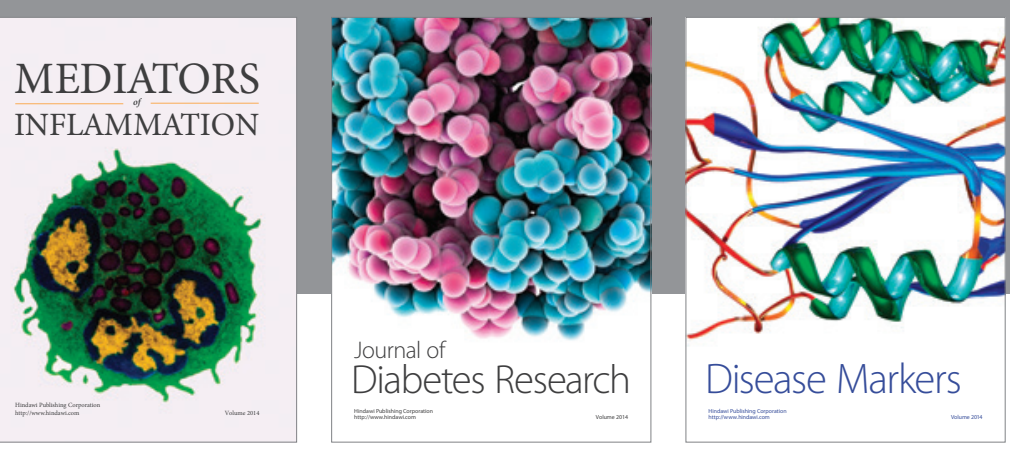

Disease Markers

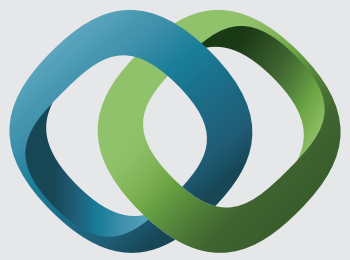

\section{Hindawi}

Submit your manuscripts at

https://www.hindawi.com
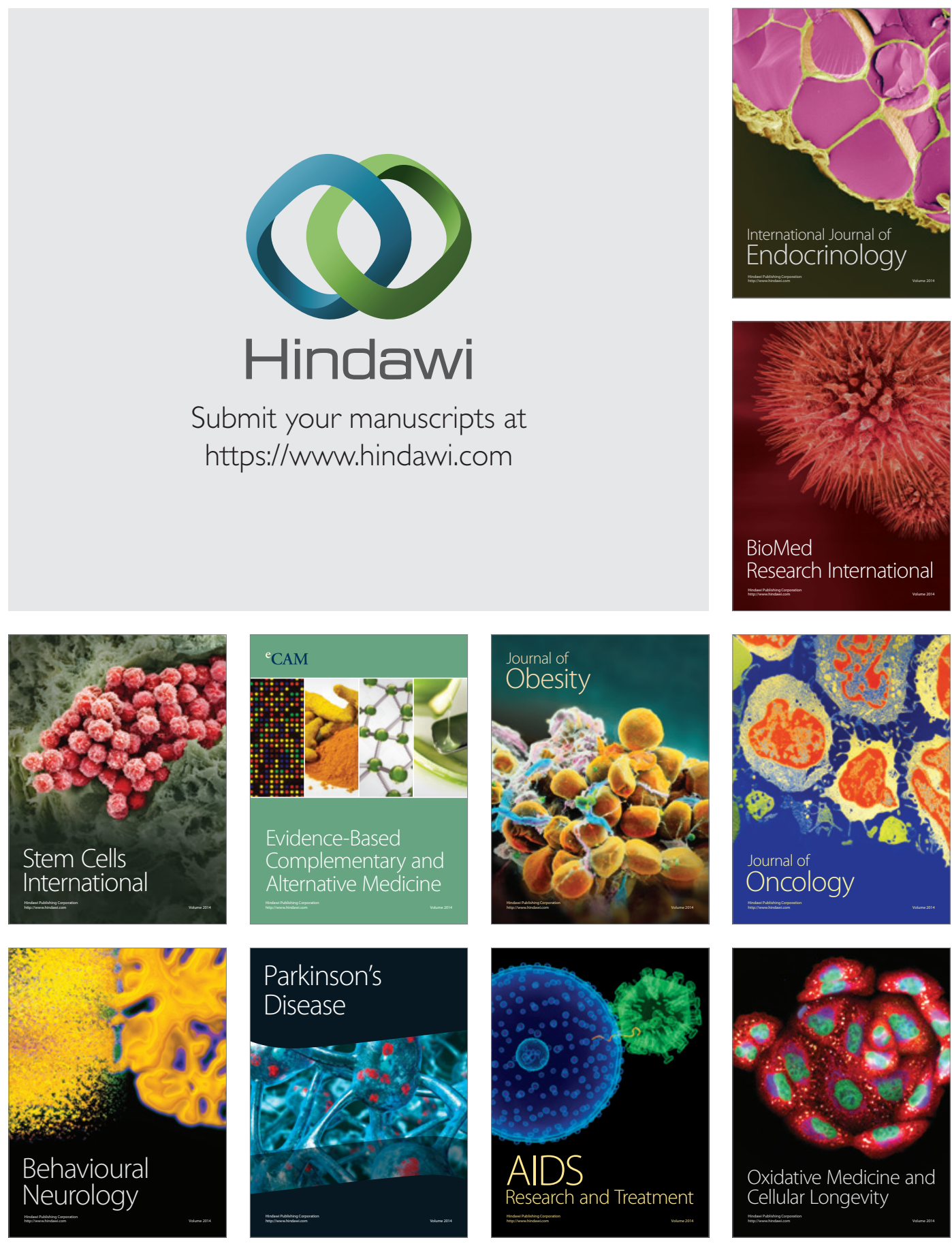